\title{
Design of new casting alloys of Al-Mg-Si-Mn system with alloying additions, its structure, and mechanical properties
}

\author{
Projektowanie nowych stopów odlewniczych \\ układu Al-Mg-Si-Mn z dodatkami stopowymi \\ wraz z ich strukturą i właściwościami mechanicznymi
}

\begin{abstract}
The strength of Al-Mg-Si-Mn casting alloy strongly depends on $\mathrm{Mg}$ content in solid solution and precipitation of strengthening phases. Alloys with the nominal composition AlMg5Si2 Mn with addition of $\mathrm{Li}$ and $\mathrm{Ti}+\mathrm{Zr}$ were studied by means of differential scanning calorimetry (DSC), transmission electron microscopy (TEM) and energy dispersive X-Ray analysis (EDX). DSC measurements show that the eutectic melting temperature was about $595^{\circ} \mathrm{C}$ and it is higher than that of commercial A356 casting alloy. The macro- and microhardness tests show that in as-cast state hardness were higher than for A356 and continuously growth during artificial aging. TEM investigations reveal that during artificial aging three different precipitation types are forms in the alloy matrix. Two of them belong to the different structures of $\mathrm{Mg}_{2} \mathrm{Si}$ precipitates. Appearance of the third one identified as $\delta^{\prime}-\mathrm{Al}_{3} \mathrm{Li}$ phase represent that Al-Mg-Si system can be successfully used for designing of Li-containing casting alloy which is not developed yet.
\end{abstract}

Keywords: Al-Mg-Si-Mn alloy, casting, Lithium, heat treatment, mechanical properties

\section{Streszczenie}

Wytrzymałość stopu Al-Mg-Si-Mn w dużym stopniu zależy od zawartości Mg w roztworze stałym i wydzieleń faz wzmacniających. Stopy o nominalnym składzie AlMg5Si2Mn z dodatkiem Li i Ti + Zr badano za pomocą różnicowej kalorymetrii skaningowej (DSC), transmisyjnej mikroskopii elektronowej (TEM) i dyspersyjnej analizy promieniowania rentgenowskiego (EDX). Pomiary DSC pokazują, że eutektyczna temperatura topnienia wynosiła około $595^{\circ} \mathrm{C}$ i była wyższa niż w przypadku komercyjnego stopu odlewniczego A356. Testy makro- i mikrotwardości pokazują, że w stanie po odlaniu twardość była wyższa niż w przypadku A356 i stale rosła podczas sztucznego starzenia. Badania TEM wykazały, że podczas sztucznego starzenia w osnowie stopu występują trzy różne rodzaje wydzieleń. Dwa z nich należą do wydzieleń $\mathrm{Mg}_{2}$ Si o różnej strukturze. Pojawienie się trzeciej,

Viktoriya Boyko Associated Professor: National Technical University of Ukraine, Igor Sikorsky Kyiv Polytechnic Institute, Kiev, Ukraine; Edward Czekaj Professor, Małgorzata Warmuzek Professor: Foundry Research Institute, Krakow, Poland; Kostiantyn Mykhalenkov Professor: National Technical University of Ukraine, Igor Sikorsky Kyiv Polytechnic Institute, Kiev, Ukraine; kvmykhalenkov@gmail.com 
zidentyfikowanej jako faza $\delta^{\prime}-\mathrm{Al}_{3} \mathrm{Li}$, oznacza, że układ Al-Mg-Si może być z powodzeniem stosowany do projektowania stopu odlewniczego zawierającego Li, który jeszcze nie został opracowany.

Słowa kluczowe: stop Al-Mg-Si-Mn, odlewanie, lit, obróbka cieplna, właściwości mechaniczne

\section{Introduction}

Automotive and aerospace industries are strongly interested in the development of new alloys for the production of lightweight constructions. In this context, alloys of the Al-Mg-Si system are considered as promising candidates for the production of sheets and extruded parts using wrought alloys $(6061,6005$, etc.) and thin-wall casting using the AIMg5Si2Mn alloy. Today, it has been established that Al-Mg-Si casting alloys possess good corrosion resistance, weldability, high surface finishing, and (in particular) good mechanical properties.

The data on the possibility of improving the properties of AlMg5Si2Mn by alloying it with $\mathrm{Cu}, \mathrm{Zn}, \mathrm{Cr}, \mathrm{Ti}, \mathrm{Zr}$, Sc $+\mathrm{Zr}$, and $\mathrm{Li}$ as well as using heat treatment is rather limited and somewhat controversial [1-4]. It was reported that the AlMg3Si1 alloy containing $\mathrm{Sc}+\mathrm{Zr}$ in the T5 state shows an ultimate tensile strength (UTS) of $270 \mathrm{MPa}$ at room temperature and $265 \mathrm{MPa}$ at $250^{\circ} \mathrm{C}$ [1], all while showing good thermal stability. The work of Petkow et al. [2] demonstrate that the AIMg5Si2Mn alloy cast into permanent mold shows only a slight increase of tensile and ultimate tensile strength after T6 treatment together with a dramatically low fracture elongation of about $2.5 \%$ for temper $F$, decreasing to $1.4 \%$ after artificial aging.

The authors' data and literature information such as [5] shows that the UTS of commercial A356 T6 may reach $300 \mathrm{MPa}$ and an elongation to fracture of $6.0 \%$. Comparable to A356 is the permanent mold cast AIMg5Si2Mn [6], where its ultimate tensile strength varies from $255 \mathrm{MPa}$ to $298 \mathrm{MPa}$ and elongation is within a range of 1.2-3.2\%. The elongation is one order lower than that of the AIMg5Si2Mn $+0.2 \mathrm{wt}$.\% Ti alloy subjected to high pressure die casting (HPDC), where it can reach 15\% [3] in the as-cast state.

Similar to heat treatment, the effect of the additional alloying of the AIMg5Si2 Mn alloy by $\mathrm{Li}$ or $\mathrm{Ti}+\mathrm{Zr}$ (for example) on the structure formation and properties have yet to be satisfactory considered. From the early work of Fridlyander et al. [7], it is clear that the addition of $\mathrm{Li}$ to Al-Cu or Al-Mg alloys can significantly enhance their properties while simultaneously decreasing their density.

Over the last few years, breakthroughs in the development of Al-Cu-Li and Al-Mg-Li wrought alloys have been achieved. However, there is no Li-containing casting alloy designed as of yet. It was proposed to use an AIMg5Si2Mn casting alloy as the base material to design a Li-containing casting alloy. This idea is based on the composition of the $\alpha$-Al solid solution in AIMg5Si2Mn alloy that consists of $2.4 \mathrm{wt} . \% \mathrm{Mg}, 0.3-0.4 \mathrm{wt} . \% \mathrm{Mn}$, and the absence of Si. Subsequently, the grains of the $\alpha$-Al solid solution would be similar 
to the Al-Mg alloy, and the addition of Li may enhance the mechanical properties of the material via precipitation of the nano-scale particles.

Thus, the purpose of the present paper is to establish the effect of $\mathrm{Li}$ and $\mathrm{Ti}+\mathrm{Zr}$ additions on the microstructure and mechanical properties of the Al-Mg-Si-Mn casting alloy in the as-cast state and after heat treatment.

\section{Materials and experimental procedure}

The nominal composition of the alloys under consideration are represented in Table 1. The alloy having a composition of Al5Mg2Si0.6Mn (denoted as $\mathrm{H}$ ) was selected as the base material.

Table 1. Nominal composition of alloys

\begin{tabular}{|c|c|c|c|c|c|c|}
\hline \multirow{2}{*}{ Alloy } & \multicolumn{7}{|c|}{ Elements content, wt.\% (Al-balance) } \\
\cline { 2 - 7 } & $\mathbf{M g}$ & $\mathbf{S i}$ & $\mathbf{M n}$ & $\mathbf{L i}$ & $\mathbf{T i}$ & $\mathbf{Z r}$ \\
\hline $\mathrm{H}$ & 5.0 & 2.0 & 0.6 & - & - & - \\
\hline $\mathrm{L}$ & 5.0 & 2.0 & 0.6 & 1.0 & - & - \\
\hline $\mathrm{T}$ & 5.0 & 2.0 & 0.6 & - & 0.1 & 0.1 \\
\hline
\end{tabular}

Alloys $\mathrm{H}, \mathrm{L}$, and T were prepared in an electric resistant furnace using graphite crucibles. As master alloys, AIMg50, AISi25, AIMn26, AlLi5, AlZr10, AlTi6, and high purity aluminum (A99.997) were used. Pure aluminum was charged into a crucible preheated to $720^{\circ} \mathrm{C}$. After superheating up to $720^{\circ} \mathrm{C}$, the master alloys (preheated to $350^{\circ} \mathrm{C}$ ) were added to the melt. After all of the additions, the melt was degassed in an argon atmosphere for 10 minutes.

Two types of heat treatment were applied. The first type is the solution treatment, which is performed in an electrical resistance furnace. After the solution treatment, the specimens were quenched into water at room temperature. The second type of heat treatment is $\mathrm{T} 6$, which combines the solution treatment at $570^{\circ} \mathrm{C}$ ( $30 \mathrm{~min}, 1$ and 1.5 hours) and quenching in water at room temperature and artificial aging. Artificial aging was conducted in a forced circulation air furnace at $175^{\circ} \mathrm{C}$ for different times.

Differential scanning calorimetry (DSC) measurements were performed using a NETZSCH DSC 404 instrument. During the DSC measurements, the specimens were protected by argon with a flow rate of $75 \mathrm{ml} \mathrm{min}^{-1}$. The measurements were taken within a temperature range of $20-700^{\circ} \mathrm{C}$ at a heating rate of $10^{\circ} \mathrm{C}$ per min.

Samples for scanning electron microscopy (SEM) and transmission electron microscopy (TEM) were prepared using conventional metallographic techniques. The composition of the phases was measured by an EDX analysis. 
Hardness was measured by a Brinell hardness testing machine (HB) with a ball diameter of $2.5 \mathrm{~mm}$ and a load of $62.5 \mathrm{~kg}$; the time of loading was $10 \mathrm{sec}$. Microhardness tests were carried out on the polished non-etched specimens on a Duramin-2 microhardness tester at $\mathrm{HV}_{0.05}$ with a standard indentation time. Tensile tests were carried out using an INSTRON 5582 testing machine according to the EN ISO 6892-1 standard. Tensile samples were also prepared according to this standard.

\section{Results and discussion}

\section{Differential scanning calorimetry}

Figure 1 shows the evolution of heat flow for the $\mathrm{H}, \mathrm{L}$, and $\mathrm{T}$ alloys as compared to the commercial A356 alloy. The first endothermic effect corresponds to the melting of the (Al) $+\left(\mathrm{Mg}_{2} \mathrm{Si}\right.$ ) eutectic (denoted as 1$)$. This thermal effect starts at $T_{\text {eut_onset }}=594^{\circ} \mathrm{C} \pm 3^{\circ} \mathrm{C}$, and the maximum peak temperature is $T_{\text {peak } \_1}=602^{\circ} \mathrm{C} \pm 3^{\circ} \mathrm{C}$. The second heat effect (denoted as 2) corresponds to the melting of $\alpha$-Al. The maximum level of the second peak is $T_{\text {peak } \_1}=621^{\circ} \mathrm{C} \pm 3^{\circ} \mathrm{C}$. Therefore, it was experimentally confirmed that the initial melting point of the alloys of Al-Mg-Si is $594^{\circ} \mathrm{C} \pm 3^{\circ} \mathrm{C}$, which is $26^{\circ} \mathrm{C}$ higher than the eutectic melting temperature of the $\mathrm{A} 356$ commercial casting alloy.

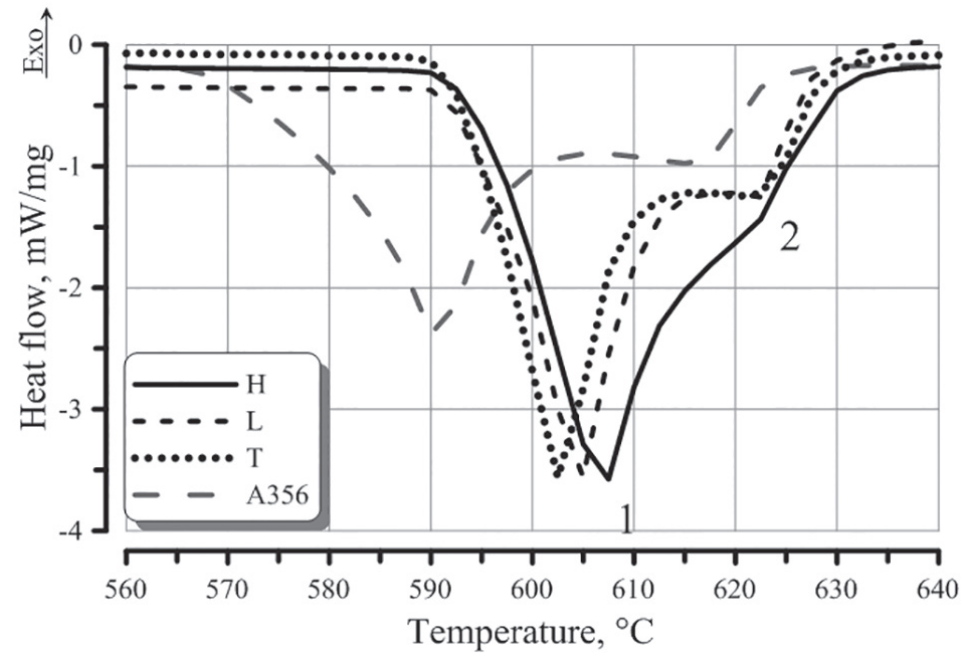

Fig. 1. DSC curves for representative commercial alloys, lines described in text

In order to explain these effects, the DSC data was compared with a phase diagram of Al- $\mathrm{Mg}_{2} \mathrm{Si}$ (Fig. 2). The results of the DSC of the base alloy (sample H) fully 
coincide with those obtained for samples $T$ and $\mathrm{L}$. This demonstrates that the addition of $0.1 \mathrm{wt} . \% \mathrm{Ti}+0,1 \mathrm{wt} . \% \mathrm{Zr}$ and $1 \mathrm{wt} . \% \mathrm{Li}$ has no effect on the type of melting and solidification of the Al-Mg-Si-Mn casting alloy's system.

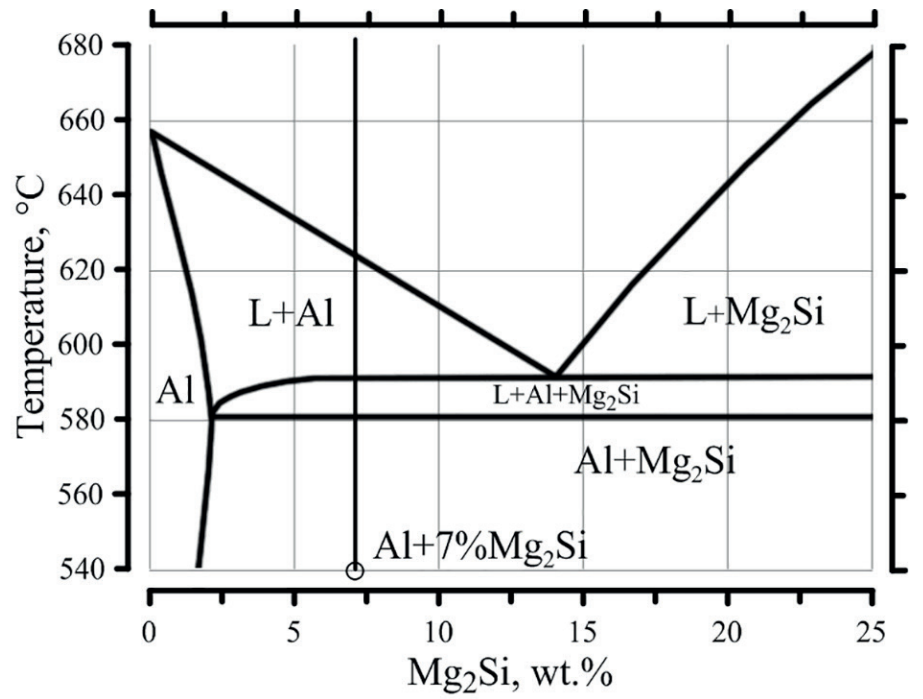

Fig. 2. Phase diagram of $\mathrm{Al}-\mathrm{Mg}_{2} \mathrm{Si}$

\section{Microstructure investigation}

The structures of the base alloy and after the addition of $\mathrm{Li}$ and $(\mathrm{Ti}+\mathrm{Zr})$ are shown in Figure 3. All alloys exhibit equiaxed grain structures, and the four phase constituents can be clearly seen; namely:

- $\alpha$-Al solid solution (appeared gray, denoted as 1 ),

- (Al) + $\left(\mathrm{Mg}_{2} \mathrm{Si}\right.$ ) eutectic (appeared dark, denoted as 2),

- $\mathrm{Mg}_{2} \mathrm{Si}$ primary crystals (appeared dark, denoted as 3),

- Al(Mn,Fe)Si phase (appeared white, denoted as 4).

The preferential morphology of $\alpha-\mathrm{Al}$ is a dendritic with long primary arms for all three alloys. The (Al) $+\left(\mathrm{Mg}_{2} \mathrm{Si}\right)$ eutectic has a lamellar morphology where long $\mathrm{Mg}_{2} \mathrm{Si}$ plates alternate with the $\alpha-\mathrm{Al}$ (Fig. 4). The primary $\mathrm{Mg}_{2} \mathrm{Si}$ crystals have regular polyhedral shapes and are situated in the centers of the eutectic colonies. The addition of $\mathrm{Li}$ cause the modification effect on the eutectic lamellas, transforming them from plates into fibers (which was observed on the deep-etched specimens). The addition of ( $\mathrm{Ti}+\mathrm{Zr}$ ) produces a slight grain refinement effect. The length of the dendrite arms in alloy $T$ is smaller as compared to the $\mathrm{H}$ and $\mathrm{L}$ alloys. 
a)

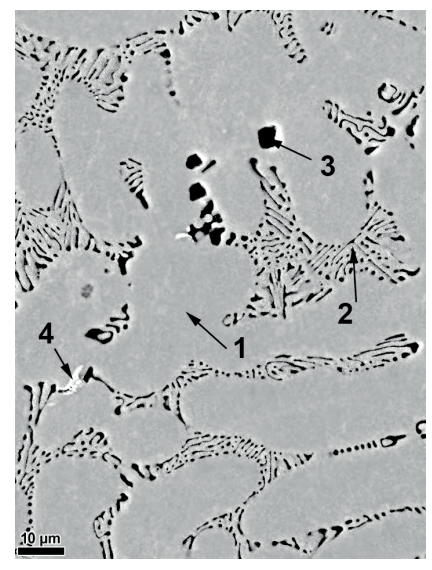

b)

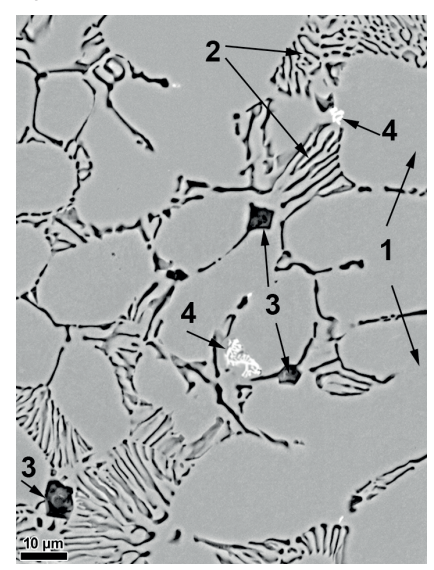

c)

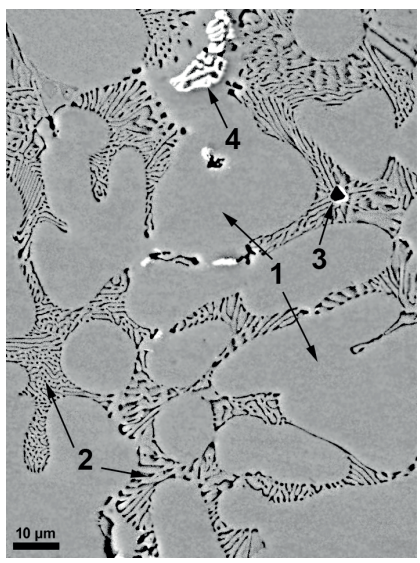

Fig. 3. Microstructure of $H(a), L(b)$, and $T$ (c) alloys in as-cast states

a)

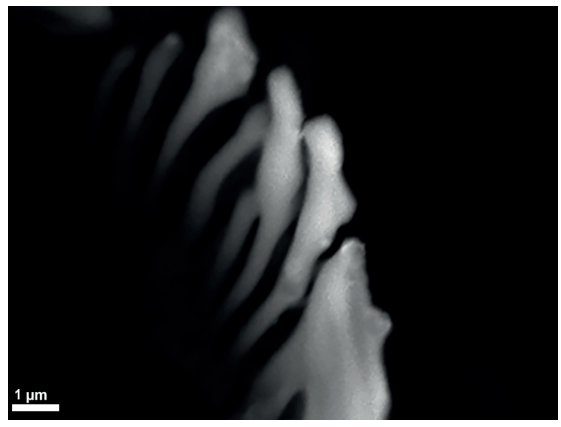

b)

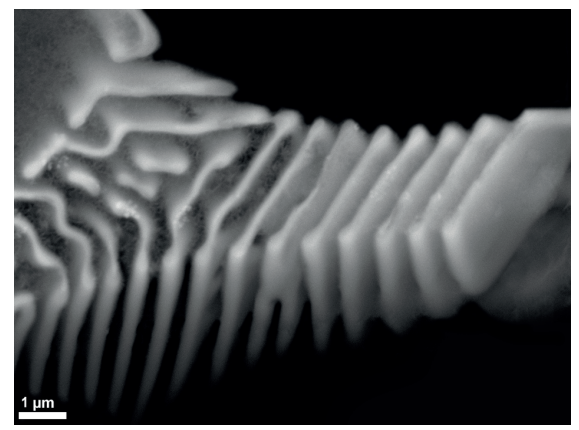

Fig. 4. Morphologies of (Al) + (Mg2Si) eutectic in: a) L alloy; b) T alloy

\section{Element distribution}

$\alpha$-Al grain. In spite of the morphological difference caused by the modification effect of the Li addition, the composition of the $\alpha$-Al matrix of the tested alloys varies only slightly. The $\alpha$-Al solid solution of the L and T alloys contains Mg and Mn (see Tab. 2). The Mg content in the solid solution measured by SEM EDX at $15 \mathrm{kV}$ acceleration voltage was 2.44 wt.\%. The Mg distribution across the dendrite arm is not homogeneous and varies within a range of 2.2-2.5 wt.\% for the $L$ alloy and of 2.5-2.6 wt.\% for the T alloy. For all alloys, the Mn content in the $\alpha$-Al solid solution was $0.45 \pm 0.05 \mathrm{wt} . \%$. In the T alloy, the $\mathrm{Ti}$ and $\mathrm{Zr}$ concentration was $0.2 \mathrm{wt} . \%$. Its distribution seems to be inhomogeneous and reaches 0.33 wt.\% at some points (close to the center of the dendrite arms). A small Si content was detected in the case of SEM EDX analysis; this obviously originated from 
the surrounding $\mathrm{Mg}_{2} \mathrm{Si}$ lamellas or those lying beneath the surface. The Si concentration in the $\alpha$-Al grains of each of the alloys was less than $0.4 \mathrm{wt} . \%$. The average composition of the $\alpha$-Al matrix for all samples is represented in Table 2 .

Table 2. Average composition of $\alpha-A l$ solid solution in $H, L$, and T alloys measured by SEM EDX

\begin{tabular}{|c|c|c|c|c|c|c|c|}
\hline \multirow{2}{*}{ Alloy } & \multicolumn{7}{|c|}{ Elements content, wt.\% } \\
\cline { 2 - 8 } & Al & Mg & Si & Mn & $\mathbf{T i}$ & $\mathbf{Z r}$ & total \\
\hline H & 96.63 & 2.57 & 0.34 & 0.46 & - & - & 100.00 \\
\hline L & 96.56 & 2.60 & 0.39 & 0.45 & - & - & 100.00 \\
\hline T & 96.53 & 2.28 & 0.32 & 0.47 & 0.21 & 0.20 & 100.00 \\
\hline
\end{tabular}

Eutectic. The EDX spectra of the lamellas excluding the Al from the quantification results gave a composition of the eutectic lamella very close to the stoichiometry of $\mathrm{Mg}_{2} \mathrm{Si}$; namely, $\mathrm{Mg} 62.5$ at.\% and Si 31.2 at.\%. The EDX spectra of the interlamella spacing showed an enrichment by Mg and Si (Tab. 3).

Table 3. Average composition of interlamella spacing measured by SEM EDX

\begin{tabular}{|c|c|c|c|c|}
\hline \multicolumn{5}{|c|}{ Elements content, wt.\% } \\
\hline $\mathbf{A l}$ & $\mathbf{M g}$ & $\mathbf{S i}$ & $\mathbf{M n}$ & total \\
\hline 80.16 & 12.00 & 7.27 & 0.57 & 100.00 \\
\hline
\end{tabular}

\section{Mn-containing phase}

In all alloys, the primary Mn-containing phase was detected; its morphology is shown in Figure 3c (denoted as 4). The chemical composition of this phase is Al 74.45 at.\%, Mn 15.78 at. \%, Si 4.73 at.\%, and Fe 0.04 at.\%, and this phase can be identified as $\alpha-\mathrm{Al}(\mathrm{Mn}, \mathrm{Fe}) \mathrm{Si}$ (which is often observed in commercial aluminum casting alloys after $\mathrm{Mn}$ addition).

\section{Primary $\mathrm{Mg}_{2} \mathrm{Si}$ crystals}

Under equilibrium conditions, the stoichiometric composition of $\mathrm{Mg}_{2} \mathrm{Si}$ is 66.7 at.\% $\mathrm{Mg}$ and 33.3 at.\% $\mathrm{Si}$ (the ratio of $\mathrm{Mg} / \mathrm{Si}$ is 2:1). In the fracture sample (crystal 1 in Figure $5 \mathrm{a}$ ), the chemical composition of the primary $\mathrm{Mg}_{2} \mathrm{Si}$ corresponds to the stoichiometric composition (Tab. 4). The resulting ratio of Mg/Si for the deep-etched samples (crystal 2 in Figure $5 b$ and crystal 3 in Figure $5 c$ ) are 1:1 and 1.3:1, respectively. The deviation of the measured composition of the primary $\mathrm{Mg}_{2} \mathrm{Si}$ crystals from stoichiometry is mainly attributed to the oxidation. 
a)

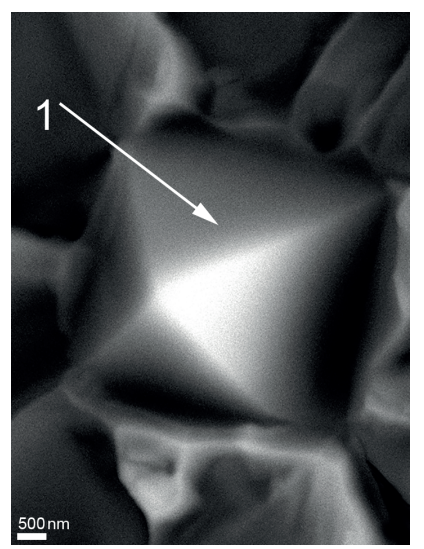

b)

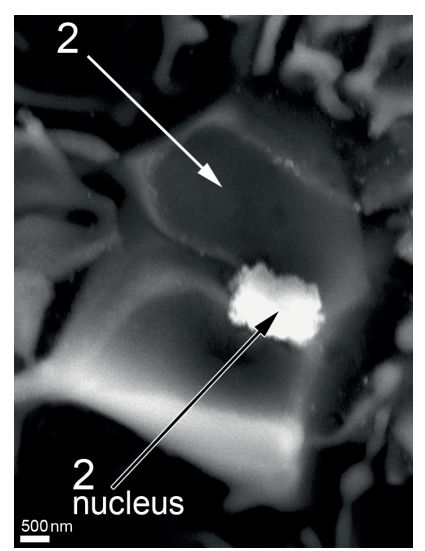

c)

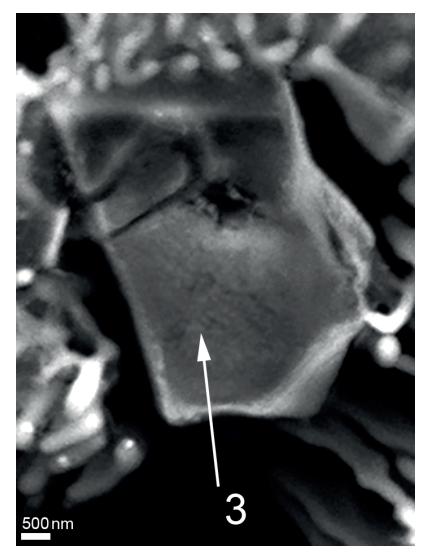

Fig. 5. Morphologies of $\mathrm{Mg}_{2}$ Si primary crystals in AIMg5Si2Mn casting alloys: a) fracture surface of T alloy; b) deep-etched T alloy; c) deep-etched L alloy

Table 4. Chemical composition of $\mathrm{Mg}_{2}$ Si primary crystals in L and T alloys measured by SEM EDX

\begin{tabular}{|c|c|c|c|c|c|c|c|c|c|}
\hline \multirow{2}{*}{ Spectrum } & \multicolumn{10}{|c|}{ Elements content, $\mathbf{w t .} \%$} \\
\cline { 2 - 12 } & $\mathbf{0}$ & $\mathbf{M g}$ & $\mathbf{S i}$ & $\mathbf{M n}$ & $\mathbf{T i}$ & $\mathbf{Z r}$ & $\mathbf{A l}$ & rest & total \\
\hline 1 & 1.43 & 60.03 & 35.20 & 0.14 & - & - & 2.88 & 0.32 & 100.00 \\
\hline 2 & 31.65 & 33.17 & 31.55 & - & - & - & 3.64 & - & 100.00 \\
\hline $\begin{array}{c}2 \text { (nucleation } \\
\text { particle) }\end{array}$ & 33.71 & 13.92 & 10.73 & 0.95 & 28.31 & 1.32 & 2.79 & 5.35 & 100.00 \\
\hline 3 & 31.76 & 33.98 & 25.20 & - & - & - & 9.05 & $\mathrm{v}$ & 100.00 \\
\hline
\end{tabular}

\section{Precipitates}

In the as-cast state, the solid solution grains contain plate-like particles (Fig. 6a). As can be seen, several plate-like precipitates are aligned in the horizontal direction (denoted as 3). On the right, they are connected by a curved line, which could be identified as a dislocation (line 1). In work [8], it was shown that these particles are formed after natural aging as a result of heterogeneous nucleation on the dislocations. These are most likely particles of the $\beta^{\prime}-\mathrm{Mg}_{9} \mathrm{Si}_{5}$ phase. In alloys after homogenization, these precipitates are absent, which indicates their dissolution during heating (Fig. 6b). Artificial aging results in re-precipitation of the $\beta^{\prime \prime}$-phase, as can be seen in Figure $6 c$. In Figure $6 c$, three morphologies of the precipitates are shown. The first one is long needles lying in perpendicular directions and marked as $\beta$ ". The second type of precipitate are cubic-shaped plates; these can be identified as $\beta-\mathrm{Mg}_{2}$ Si particles. The third type of precipitate are the 
tetragonal-shaped particles marked as $\delta$ '. Since $L$ alloy was alloyed with $L i$, these precipitates can be identified as $\delta^{\prime}$ - the $\mathrm{Al}_{3}$ Li phase.

a)

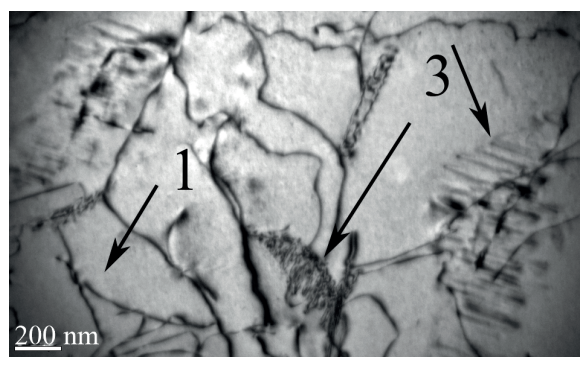

b)

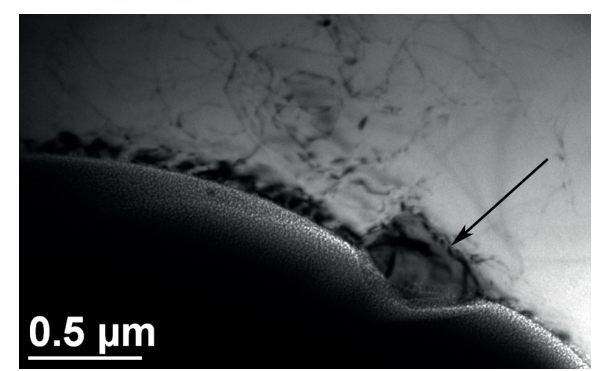

c)

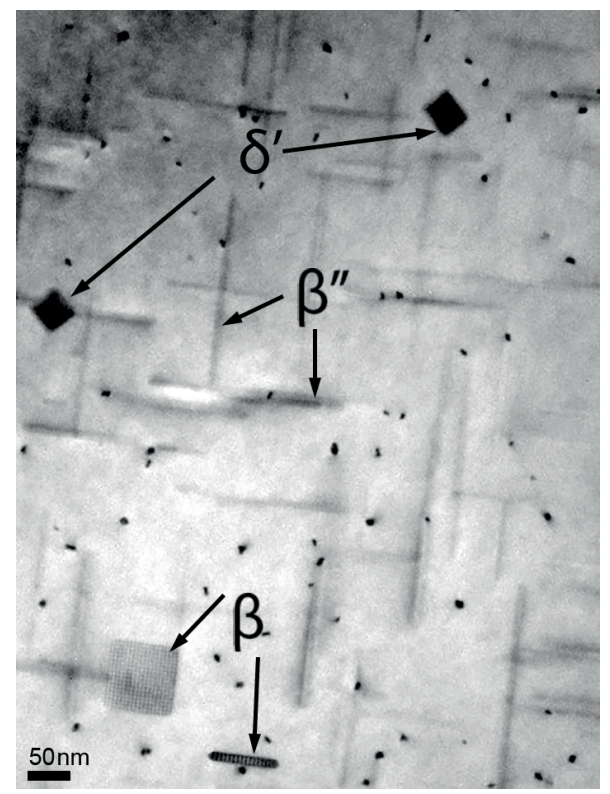

Fig. 6. TEM bright field images of precipitates in AlMg5Si2Mn casting alloys: a) as-cast state; b) after homogenization; c) alloy L after artificial aging

\section{Mechanical tests}

The results of the hardness measurements and tensile tests are summarized in Figure 7 and Table 5. One can expect that the hardness of the tested alloys should initially grow and then gradually decreases due to the growth of $\beta$-precipitates and loss of their coherency with the aluminum matrix.

A solution treatment for 30 mins. results in a significant decrease in both $\mathrm{HB}$ and $\mathrm{HV}_{0.05}$. Longer soaking leads to a further decrease in hardness. The decrease in hardness is the result of two processes that simultaneously occur during heating. The first one is eutectic spheroidization. The higher solution treatment temperature leads to faster eutectic lamella fragmentation into smaller segments and the spheroidizing effect. The second process is the dissolution of the $\beta$ " precipitates formed during natural aging. After 30 mins. of artificial aging, increases in $\mathrm{HB}$ and $\mathrm{HV}_{0.05}$ were detected for all of the studied alloys. After 90 mins. of aging, hardness and microhardness reached the maximum levels for the $L$ and $T$ alloys. Prolonged aging up to 1800 mins. showed a slight decrease in HB for the L and T alloys. Same hardness changes were observed during the $\mathrm{HV}_{0.05}$ measurements. 
a)

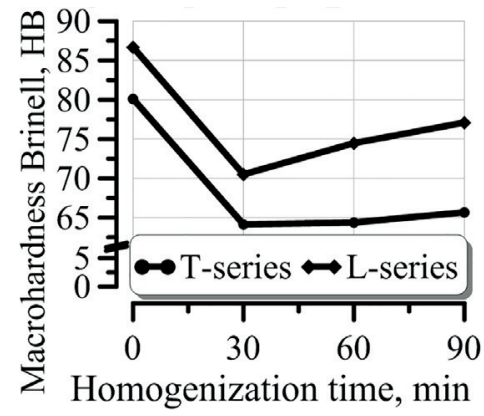

c)

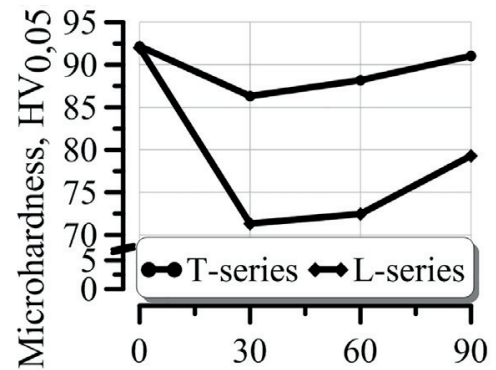

Homogenization time, $\min$ b)

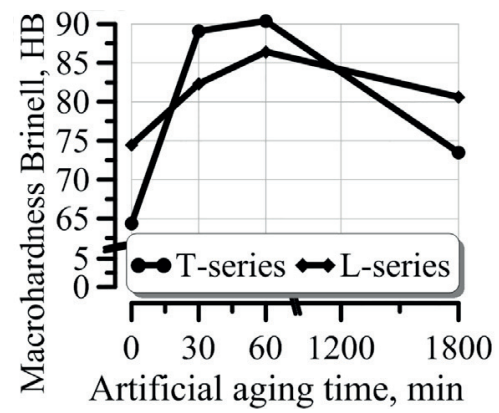

d)

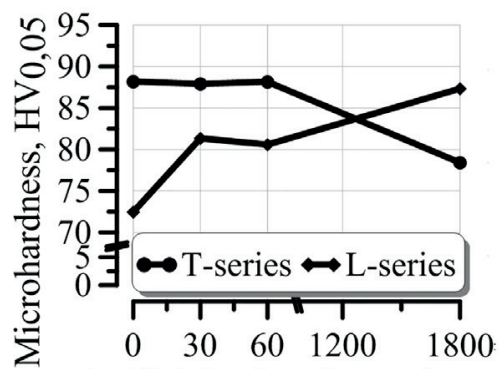

Artificial aging time, min

e)

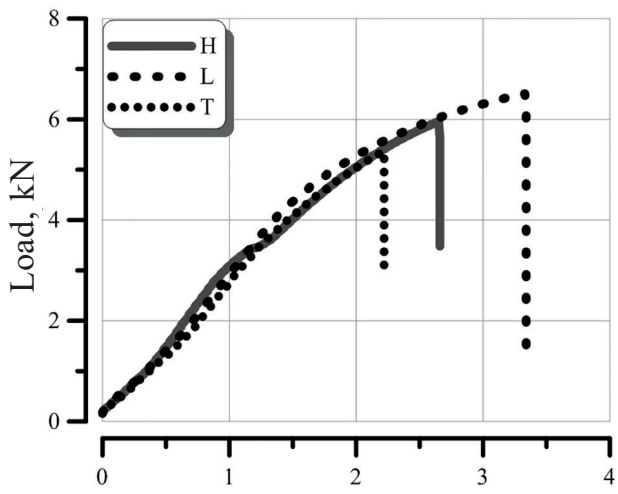

Elongation, $\mathrm{mm}$

Fig. 7. Mechanical properties of AIMg5Si2Mn casting alloys: $(a, b)$ macrohardness; $(c, d)$ microhardness; e)tensile curves

The tensile properties of the studied alloys were tested; the yield and tensile strengths are listed in Table 5. It can be seen that the tensile properties of the $\mathrm{L}$ and $\mathrm{H}$ alloys are higher than that of $\mathrm{H}$. From Figure 7 e and Table 5, one can see that Li addition provides increases in tensile strength and elongation, and this effect can be attributed to the formation of the $\delta^{\prime}-\mathrm{Al}_{3} \mathrm{Li}$ phase. 
Table 5. Results of hardness, microhardness, and tensile tests

\begin{tabular}{|c|c|c|c|c|}
\hline Alloy & $\begin{array}{c}\text { Microhardness } \\
\mathbf{H V}_{\mathbf{0 . 0 5}}\end{array}$ & $\begin{array}{c}\text { Hardness } \\
\mathbf{H B}\end{array}$ & $\begin{array}{c}\text { Tensile strength } \boldsymbol{R}_{\boldsymbol{m} \boldsymbol{\prime}} \\
\mathbf{M P a}\end{array}$ & $\begin{array}{c}\text { Yield strength } \boldsymbol{R}_{\boldsymbol{p 0 . 2 \boldsymbol { \nu }}} \\
\mathbf{M P a}\end{array}$ \\
\hline $\mathrm{H}$ & 73 & 76 & 211 & 117 \\
\hline $\mathrm{L}$ & 92 & 87 & 227 & 163 \\
\hline $\mathrm{T}$ & 92 & 80 & 190 & 138 \\
\hline
\end{tabular}

\section{Conclusions}

- The results of DSC measurements of the base alloy completely coincide with those obtained for samples $\mathrm{T}$ and $\mathrm{L}$. This indicates that the addition of alloying elements produces no effect on the melting and solidification behavior of Al-Mg-Si-Mn alloys.

- In the as-cast state, the microstructure of the Al-Mg-Si-Mn alloy consists of three phases: $\alpha$-Al solid solution grains, the (Al) $+\left(\mathrm{Mg}_{2} \mathrm{Si}\right)$ eutectic, and $\mathrm{Mg}_{2} \mathrm{Si}$ primary crystals. The $\alpha$-Al exhibits dendritic morphology with well-developed arms. The eutectic has a plate-shaped morphology.

- The alignment of precipitates formed during natural aging along the dislocations shows that the main mechanism of their formation is heterogeneous nucleation on the dislocations during the aging of the alloys.

- Both alloys of AlMg5Si2Mn + Li and AlMg5Si2Mn $+(\mathrm{Ti}+\mathrm{Zr})$ showed similar results of macro- and microhardness tests. Mechanical tests proved that solution treatment reduces the hardness of the investigated alloys due to the disintegration of the $\mathrm{Mg}_{2} \mathrm{Si}$ lamellas.

- Artificial aging leads to an increase in alloy hardness. The highest values of macroand microhardness were achieved after 30-60 minutes of aging.

\section{Acknowledgements}

The authors gratefully thank Dr. Thomas Link from Technical University Berlin (Berlin, Germany) for his valuable help in interpreting the TEM results as well as Olena Prach and Alexander Trudonoshin for providing the SEM examinations and tensile tests.

\section{References}

[1] Eigenfeld K., Franke A., Klan S., Koch H., Lenzcowski B., Pflege B.: New developments in heat resistant aluminum casting materials. Casting Plant and Technology International, 4 (2004), 4-9

[2] Petkov T., Kunstner D., Pabel T., Kneibl C., Schumacher P.: Optimizing the Heat Treatment of a Ductile AlMgSi-alloy. Giesserei-Rundschau, 59 (2012), 194-200

[3] Ji S., Watson D., Fan Z., White M.: Development of a super ductile die cast Al-Mg-Si alloy. Materials Science and Engineering, 556 (2012), 824-833. http://dx.doi.org/10.1016/j.msea.2012.07.074 
[4] Wuth M.C., Koch H., Franke A.J.: Production of steering wheel frames with an AlMg5Si2Mn alloy. Casting Plant and Technology International, 16, 1 (2000), 12-24

[5] Shabestari S.G., Shahri F.: Influence of modification, solidification conditions and heat treatment on the microstructure and mechanical properties of A356 aluminum alloy. Journal of Material Science, 39 (2004), 2023-2032

[6] Pirš J., Zalar A.: Investigations of the distribution of elements in phases present in G-AIMg5Si cast alloy with EDX/WDX spectrometers and AES. Microchimica Acta, 101, 1-6 (1990), 295-304

[7] Fridlyander J.N., Bratukhin A.G., Davydov V.G.: Soviet Al-Li Alloys of Aerospace Application, AluminumLithium. Proceedings of the Sixth International Aluminum-Lithium Conference in Garmisch-Partenkirchen, Germany, Peters M. and Winkler P.-J. eds., Vol. 1, 1991, 35-42

[8] Boyko V., Link T., Korzhova N., Mykhalenkov K.: Microstructure characterization of AIMg5Si2Mn casting alloy. In: Materials Science and Technology (MS\&T) 2013, October 27-31, Montreal, Quebec, Canada, 2013, 1331-1338 